\title{
Aşırı Doz Siklopentolat Göz Damlasına Bağlı Gelişen Santral Antikolinerjik Sendrom
}

\author{
Central Anticholinergic Syndrome Induced by Overdose \\ Cyclopentolate Eye Drops
}
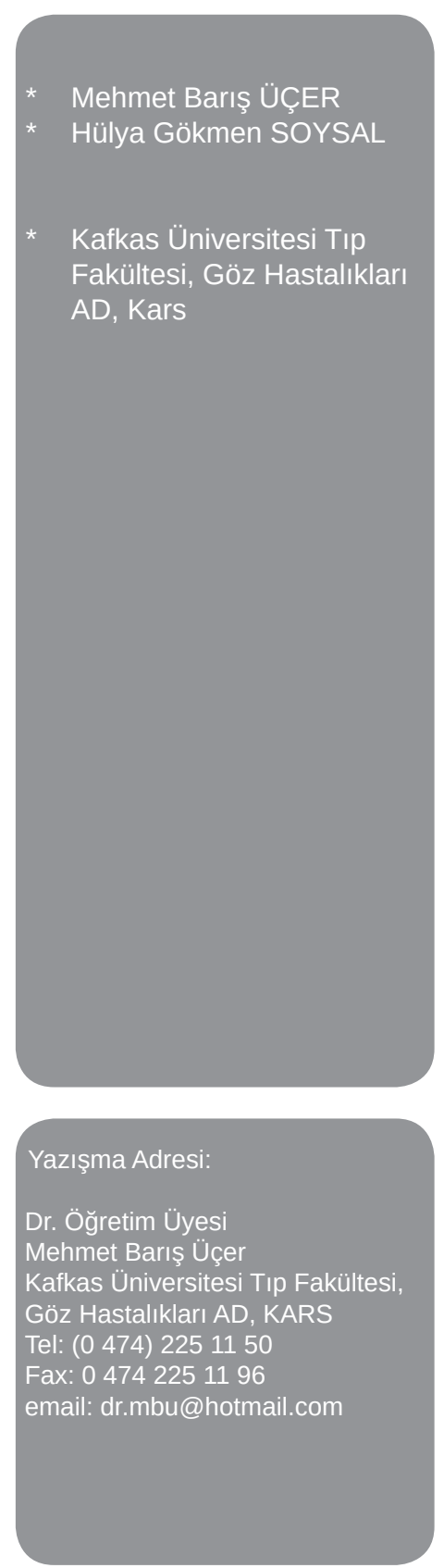

Öz

Siklopentolat hidroklorür \%1 damla göz kliniklerinde çok sık kullanılan topikal midriyatik ve sikloplejik bir ilaçtır. Bu olguda sekiz yaşındaki hastaya yanlışııla toplamda 16 damla siklopentolat hidroklorür $\% 1$ döküldükten sonra gelişen santral antikolinerjik sendrom sunulmuştur. Dizartri, ataksik yürüyüş, görsel halüsinasyon, ağız şapırdatma, dizoryantasyon ve yüzde kızarıklık gelişen hasta, tıbbi gözetim altında tutulmuş ve tüm bulgular 6 saat içinde kendiliğinden düzelmiştir. Özellikle uygun dozda kullanılmayan siklopentolat göz damlasına bağıı sistemik yan etkiler gelişebileceği için bu hastalar gözlem altında tutulmalıdır.

Anahtar Kelimeler: Siklopentolat hidroklorür \%1, toksisite, aşırı doz

\begin{abstract}
Cyclopentolate hydrochloride $\% 1$ is a commonly used drug as a topical mydriatic and cycloplegic agent in ophthalmology clinics. In this report, an eight years old patient was presented who diagnosed as central anticholinergic syndrome after accidental instillation of a total dose of 16 drops cyclopentolate hydrochloride \%1. Patient was strickly monitered as for the symptoms of dysarthria, gait ataxia, visual hallucination, mouth sneezing, disorientation and facial redness. All findings were resolved spontaneously within 6 hours. Cyclopentolate eye drops can cause systemic side effects especially if not used at appropriate dose, thus these patients should be observed.
\end{abstract}

Keywords: Cyclopentolate hydrochloride \%1, toxicity, overdose

\section{Giriş}

Siklopentolat hidroklorür damla, oftalmolojik muayenede ve tedavide sıklıkla kullanılan topikal sentetik antikolinerjik bir ajandır. Asetilkolinle yarışmalı antagonizma yaratarak antimuskarinik etki gösterir. İris sfinkter kasında ve siliyer kasta kolinerjik uyarıyı engelleyerek midriyazise ve sikloplejiye yol açar. Sikloplejik etki, uygulandıktan 30-60 dk sonra başlar ve 24 saat boyunca devam edebilir (1). Çocuklarda sağlıklı bir refraksiyon ve fundus muayenesi ancak farmakolojik olarak siklopleji ve midriyazis sağlandıktan sonra mümkün olmaktadır. Ülkemizde siklopentolatın \%1'lik ticari solüsyonu kullanımdadır. Siklopentolatın özellikle yüksek konsantrasyon ve doza bağlı olarak 
artan oranda sistemik yan etkilerinin görülebileceği bilinmektedir $(2,3)$.

Bu çalışmada, \%1'lik siklopentolat göz damlası uygulaması sonrası santral antikolinerjik sendrom gelişen çocuk yaş grubu bir olgu sunulmuştur.

\section{Olgu}

Uzağı net görememe şikayeti nedeniyle ailesi tarafından polikliniğe getirilen 8 yaşındaki kız çocuğunun görme keskinliği her iki gözde 7/10 seviyesindeydi. Gözler primer pozisyonda ortoforik olup refraksiyon muayenesi için hastanın ailesine siklopentolat hidroklorür \%1 damla verilerek her iki gözüne 5 dakika arayla üç kez birer damla damlatılması tariflendi. Bir saat sonra hasta çağırıldığında ailesinden, kızlarının garip davrandığı ve her bir göze 8'er damla olmak üzere toplamda 16 damla döktükleri öğrenildi. Hastada dizartri, ataksik yürüyüş, görsel halüsinasyon, ağız şapırdatma ve yer, zaman, kişi oryantasyon bozukluğu tespit edilmesi üzerine acil servise yönlendirildi. Fizik muayenesinde aksiller vücut sıcaklığı $37^{\circ} \mathrm{C}$, nabız 83/ $\mathrm{dk}$, arteryal tansiyon 100/70 $\mathrm{mmHg}$, pulse oksimetre ile oksijen satürasyonu \% 97 idi. Pupiller dilate ve ışık refleksi yoktu. Yüzünde kızarıklık olan hastada başka sistemik ve nörolojik fizik muayene bulgusu saptanmadı. Aşırı doz siklopentolata bağlı santral antikolinerjik sendrom tanısıyla hasta monitorize edilerek iv serum fizyolojik infüzyonuna başlandı. Acil serviste takibe alınan hastanın yaklaşık 6 saat sonra tüm bulguları düzeldi. Pupilla dilatasyonu üç gün sonra düzeldi.

\section{Tartışma}

Siklopentolat damla göze topikal uygulandığında nazolakrimal kanala ve burun boşluğuna kolaylıkla geçer. Konjonktiva ve nazal mukozadan sistemik olarak iyi emilir. Sistemik emilim aynı zamanda orofarenks, sindirim sistemi ve deri yoluyla da gerçekleşir (4). Sistemik emilime bağlı nadir de olsa yan etkiler gelişebilmektedir. Taşikardi, santral sinir sistemi (SSS) uyarılmasına ya da baskılanmasına bağlı etkiler, dizoryantasyon, vazodilatasyon, hipertermi, ağız kuruluğu, tremor, çocuklarda epileptik nöbet, halusinasyon, deri döküntüleri ve üriner retansiyon bilinen yan etkilerdir (5).

Asetilkolin ve reseptörleri SSS'de yaygın olarak bulunmaktadır. Kolinerjik sistem hafıza, oryantasyon, uyku-uyanıklık, farkındalık gibi beyin aktivitelerininde görevlidir. Santral sinir siteminde özellikle santral kortikal ve subkortikal muskarinik reseptörlerin antagonizasyonu, santral antikolinerjik sendroma yol açar. Topikal siklopentolat kullanımına bağlı SSS toksisitesi ilk defa 1962 yılında 8 yaşında bir hastada gelişen ataksi, dizartri ve anlamsız konuşma nedeniyle Simco tarafından tanımlanmıştır (6). Toksikasyon belirtileri damla uygulamasından 20-30 dakika sonra ortaya çıkar ve 4-8 saat devam ederek sekelsiz düzelir $(7,8)$. Bu süre içerisinde hastalarda ataksi, dizartri, dizoryantasyon, halüsinasyon, öfori, nedensiz gülmeler, ajitasyon, artmış motor aktivite, konfüzyon ve deliryum izlenebilir $(6,7,9)$.

Olgumuza topikal siklopentolat uygulaması sonrası dizartri, ataksik yürüyüş, görsel halüsinasyon, ağız şapırdatma ve dizoryantasyon gibi SSS toksisite bulguları gelişmesi üzerine santral antikolinerjik sendrom tanısı konuldu. Hasta acil serviste monitorize edilerek takibe alındı.

Santral sinir sistemi toksisitesi gelişiminde güvenli eşik dozu belirlemek zordur. Siklopentolatın yüksek dozlarda ve konsantrasyonlarda toksisite riskini artırdığı gösterilmiştir $(2,3,10)$. Hatta daha düşük konsantrasyonlarda ve dozlarda dahi çocuklarda deliryum tablosu geliştiği bildirilmiştir (11). Bagheri ve ark. ise yaşları 3,5 ile 20 arasında değişen 96 hasta üzerinde $1 \mathrm{doz} \% 1$ 'lik siklopentolat uygulamasının refraksiyon muayenesi için yeterli etki gösterdiğini ve 2 ya da 3 doz uygulamaya göre daha az yan etkisi olduğunu bildirmişlerdir (12).

Siklopentolata bağlı SSS toksisitesi her yaş grubunda görülebilmekle beraber $(2,3,7,12,13)$, Mirshahi ve ark. yaptıkları literatür taraması sonucu nörolojik hastalığı olanlarda toksisite eğiliminin daha yüksek olduğuna dikkat çekmişlerdir (13).

Poliklinik şartları ne kadar yoğun olsa da hasta ve yakınları mutlaka ilaç yan etkileri hakkında bilgilendirilmeli, topikal uygulanan ilacın sistemik emilimini azaltmak için punktumlara bir süre bası yapılması anlatılmalıdır. Olgumuzda olduğu gibi damla uygulaması hasta ve yakınlarına bırakılmamalı bizzat profesyonel sağlık çalışanları tarafından yapılmalıdır. Topikal medikasyon mümkün olan en düşük konsantrasyonda ve dozda uygulanmalıdır.

Sonuç olarak sikloplejik ilaçlar yaygın olarak kullanıl- 
sa da nadiren sistemik yan etkiler gelişebilmektedir. Özellikle yüksek dozlarda ve konsantrasyonlarda yan etki görülme ihtimali artmaktadır. Sağlık çalışanları olarak bu yan etkiler unutulmamalı ve uygulama sırasında hastalar gözlem altında tutulmalıdır.

\section{Kaynaklar}

1. Lovasik JV. Pharmacokinetics of topically applied cyclopentolate $\mathrm{HCl}$ and tropicamide. Am J Optom Physiol Opt 1986; 63:787-803

2. Awan KJ. Adverse systemic reactions of topical cyclopentolate hydrochloride. Ann Ophthalmol 1976; 8: 695-698.

3. Huismans $\mathrm{H}$. Intoxikationspsychose nach Cyclopentolat-HCl (Zyklolat). Klin Monatsbl Augenheilkd 1979; 175: 100-102.

4. Haaga M, Kaila T, Salminen L, Ylitalo P. Systemic and ocular absorption and antagonist activity of topically applied cyclopentolate in man. Pharmacol Toxicol. 1998 ;82(1):19-22.

5. Gilman AG, Rall TW, Nies AS, Taylor P,eds. Goodman and Gilman's The Pharmacological Basis of Therapeutics, 8th ed. New York, NY, Pergamon Press, 1990

6. Simcoe CW. Cyclopentolate (Cyclogyl) toxicity. Report of a case. Arch Ophthalmol. 1962; 67:406-408

7. Baysal Z, Cengiz M, Oğuz H, Ganidağlı S. Central Anticholinergic Syndrome Induced by Cyclopentolate Eye Drops in A 4 Year Old Child. The Internet Journal of Emergency and Intensive Care Medicine 2006:9(1). 8. Bhatia SS, Vidyashankar C, Sharma RK, Dubey AK. Systemic toxicity with cyclopentolate eye drops. Indian Pediatr 2000;37:329-331.

9. Ağın H, Gerçek H, Kutlu A, Gülez N, Atlıhan F. Topikal siklopentolat kullanımına bağlı gelişen deliryum tablosu: Bir vaka takdimi. Çocuk Sağlığı ve Hastalıkları Dergisi 2008; 51: 39-42

10. BinkhorstRD,WeinsteinGW,BaretzRM,ClahaneAC. Psychotic reaction induced by cyclopentolate (cyclogyl); results of a pilot study and a double-blind study. Am J Ophthalmol 1963; 55:1243-1245

11. Khurana AK, Ahluwalia BK, Rajan C, Vohra AK. Acute psychosis associated with topical cyclopentolate hydrochloride. Am J Ophthalmol. 1988; 15:105(1):91

12. Bagheri A, Givrad S, Yazdani S, Reza Mohebbi M.Optimal dosage of cyclopentolate $1 \%$ for complete cycloplegia: a randomized clinical trial. Eur J Ophthalmol. $2007 ; 17(3): 294-300$.

13. Mirshahi A, Kohnen T. Acute psychotic reaction caused by topical cyclopentolate use for cycloplegic refraction before refractive surgery: case report and review of the literature. J Cataract Refract Surg. 2003 ;29(5):1026-1030. 